\title{
Seabirds and climate: knowledge, pitfalls, and opportunities
}

\section{Daniel Oro *}

Population Ecology Group, Institut Mediterrani d'Estudis Avançats, Consejo Superior de Investigaciones Cientificas - Universidad de las Islas Baleares, Esporles, Spain

\section{Edited by:}

Morten Frederiksen, Aarhus

University, Denmark

Reviewed by:

Katie M. Dugger, Oregon State

University, USA

Christophe Barbraud, Centre

National de la Recherche

Scientifique, France

*Correspondence:

Daniel Oro, Institut Mediterrani

d'Estudis Avançats, Consejo

Superior de Investigaciones

Cientificas - Universidad de las Islas

Baleares, Miquel Marques 21,

Esporles 07190, Mallorca, Spain

e-mail:d.oro@uib.es
As a physical driver of ecosystem functioning, it is not surprising that climate influences seabird demography and population dynamics, generally by affecting food availability. However, if we zoom in ecologically, seabirds are in fact very heterogeneous, ranging in size from very small to very large species (with a difference of more than two orders of magnitude in body weight), from planktivorous forms to predators of large fish and squid, from benthic to pelagic, from species with small foraging ranges to species feeding throughout the whole circumpolar region, and from resident species (at a spatial mesoscale) to trans-equatorial migrating seabirds that travel large distances across several oceanographic systems. Due to this high variability and the difficulty in obtaining direct reliable estimates of long-term food availability, global climatic indices have been extensively used in studying seabird demography and population dynamics. However, the use made by researchers of these indices has certain conceptual and methodological pitfalls, which I shall address in this review. Other factors, such as anthropogenic impacts (including oil-spills and interaction with fisheries), may further alter or confound the association between climate and seabird demography. These pitfalls and environmental noise, together with the inability to incorporate resilience, may bias our predictions regarding the future impact of global warming on seabirds, many of which have vulnerable populations.

\section{Keywords: predictive models, resilience, methodological bias, evolution, global change, climate, seabirds}

\section{HISTORICAL BACKGROUND}

A search performed in June 2014 using the words "climate \& seabird" in the ISI Web of Science resulted in 946 items. Even though some of those items dealt with other marine organisms or were focused on some related issues (such as oceanographic processes), that result represents a large number of scientific contributions on the topic of how climate may influence seabird ecology. The influence of climate on marine organisms has been extensively studied in seabirds because, compared to most other species (except some marine mammals such as seals and sealions), their demography and population dynamics can be easily monitored in breeding colonies.

Up to the 90s, the changes in demographic parameters and population size in seabirds were explored mostly in relation to intrinsic features of the colonies such as their size or the presence of predators (Hunt et al., 1986). The effects of climate (mostly in the form of oceanographic indices) on seabird ecology were seldom analyzed in those years (Myres, 1979), and research efforts were addressed mostly to determining the distribution of seabirds at sea (Abrams, 1985). The influence of oceanographic features was outlined especially when extreme and anomalous events occurred (such as cyclones or El NiñoSouthern Oscillation (ENSO) years (e.g., Blomqvist and Peterz, 1984; Graybill and Hodder, 1985), whereas some pioneering studies dealt with the relationship between climatic events and seabird mortalities (La Cock, 1986). In the 90s some papers started to highlight the potential impact of climate warming on seabirds (Burger, 1990; Brown, 1991; Duffy, 1993) and the role played by climate on bottom-up control mechanisms, food availability and its effects on seabird population dynamics (Crawford, 1991; Ainley et al., 1994). Nevertheless, it was not until the end of the 90s that the literature on climate and seabirds exponentially increased (Montevecchi and Myers, 1997; Guinet et al., 1998; Lyver et al., 1999) (see Figure 1) and that the first paper relating climate and adult survival of a seabird appeared using reliable and robust quantitative methods (Barbraud et al., 2000). That exponential phase was likely the result of the increasing interest of the scientific community about climate change in the ecological literature during those years, together with the appearance of new statistical tools and the improvement of computational power (Figure 1) (Green et al., 2005).

Given that previous papers have recently reviewed thoroughly the state-of-the-art knowledge on seabirds and climate (Schreiber, 2002; Barbraud et al., 2012; Sydeman et al., 2012; Jenouvrier, 2013; Quillfeldt and Masello, 2013), here I shall concentrate on more conceptual issues, knowledge gaps and pitfalls typical of the studies dealing with how climate influences the ecology of seabirds.

\section{CLIMATE AND ITS INFLUENCE ON SEABIRDS}

It is no surprise that bottom-up control in marine ecosystems exerted by oceanographic drivers, which is mostly controlled by 


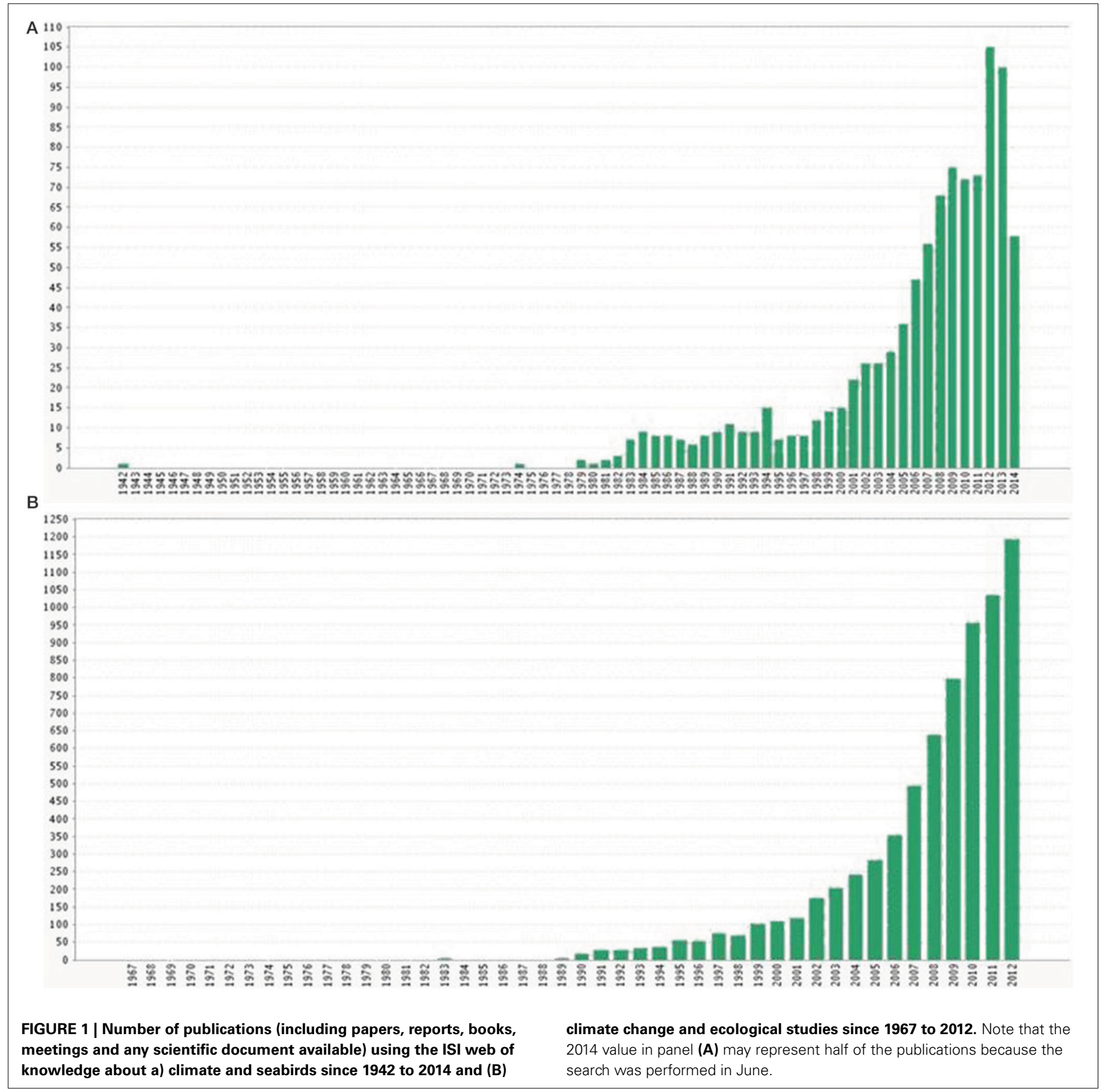

climate variables (e.g., wind, temperatures, air pressure) influence the ecology of marine top-predators such as seabirds. As it should be expected, seabirds respond to the variability in climate change and warming (e.g., Schreiber, 2002; Jenouvrier, 2013), and responses occur at both proximal (ecological) and ultimate (evolutionary) levels (Parmesan, 2006; Weimerskirch et al., 2012). The scientific literature has been sensitive to the warning message involving climate warming and papers dealing with seabirds have not been an exception (Votier et al., 2008a). Massive breeding failures following climate perturbations have attracted the attention of researchers, and records on El Niño events and its ecological consequences are a good example (e.g., Glantz, 2001; Velarde et al., 2004; Devney et al., 2009). In general, the literature shows that climate variability influences most ecological parameters analyzed, including range shifts (in breeding but mostly in foraging areas) and changes in both phenology and demographic parameters (including survival, dispersal, recruitment and breeding propensity). Back in the 80 s, some papers already recorded events of adult seabird mortality overlapping with extreme climate years (La Cock, 1986). But more unexpected has been the range of papers that have found linear relationships between adult survival and climate variables, because adult survival should be 
a highly conservative parameter due to evolutionary canalization, typical of long-lived organisms including seabirds (Stearns et al., 1995; Gaillard and Yoccoz, 2004). One possible reason is that more powerful statistical tools, such as capture-recapture models, have allowed researchers to take advantage of the large number of long-term data bases collected in the last 40-50 years on seabird ecology (mainly population trends and individually marked monitoring). With these long time series researchers can detect more subtle associations between climate factors and demographic parameters like survival, that exhibit relatively low amounts of temporal variation. In fact, the amount of available long-term data on several species and populations of seabirds is amazing, compared to other marine or even terrestrial organisms (Grosbois et al., 2008; Sydeman et al., 2012). I found up to 49 papers (some of them corresponding to several species, morphs or colonies) assessing the potential impact of climate on adult survival using methods accounting for recapture probability (Table 1). Those papers included 36 different species (most of them Procellariiformes) and seldom considered time lags between the climate index and adult survival (24\% of the cases). More than $77 \%$ of the 75 species* colonies studies found a relationship (linear in most cases) between climate and adult survival. Nevertheless, Grosbois et al. (2008) warned about several potential biases that could occur when assessing the effects of climate on survival, including the test of multiple covariates without correcting $\alpha$-values of statistical significance (in cases where classical null hypothesis statistical testing is employed for inference purposes), collinearity between those covariates and survival, or the inclusion or not of lag times when testing for those effects (see below).

Charles Darwin was fascinated by the size of seabird colonies, formed by millions of individuals. After centuries of direct harvesting, introduced mammalian predators and destruction of suitable breeding habitat, most of those colonies have been decimated, and environmental stochasticity, including climate variation, has a greater impact on population changes than it did in the past, because population sizes are smaller and closer to the quasi-extinction thresholds than ever before. Nevertheless, ecological responses of seabirds facing climate variability suggest that they can have highly resilience responses, and this should be viewed as a buffer against decline or extinction (see below) (Forcada et al., 2008; Gremillet et al., 2012). Changes in seabird populations or demographic parameters associated with climate are often described as "alterations" and "reductions," with an implied warning message or value-judgment (Martínez-Abraín and Oro, 2013). Only when researchers can show that changes in seabird ecology associated with climate variability fall outside the range of inherent variability in biological parameters (at the level of both individuals and populations) should we be concerned about the fate of a population or a species due to climatic change. In fact, much less has been published on the influence of climate on population dynamics of seabirds (e.g., Frederiksen et al., 2004b; Jahncke et al., 2004; Forcada and Trathan, 2009; Burthe et al., 2014; Woehler et al., 2014) but even in those cases it is difficult to know which percentage of the variance in population size or density is explained by climate forcing compared to other factors such as competition, density-dependence, predation or dispersal (Bustnes et al., 2013).

\section{PITFALLS AND GAPS OF THE CLIMATE-SEABIRD RESEARCH}

Scientific generalizations are helpful because the message of the concept is clearer: climate warming is a scientific fact, and the resulting changes in the biosphere follow the same fast trend. I am not going to discuss here the particularities involving climate change (e.g., spatial heterogeneity in warming, consequences for other components such as precipitation, humidity, or atmospheric pressure); however, given that I use the general term "seabirds," it is difficult to avoid dealing with the variability across taxa. Seabird body sizes range from very small to very large forms (with a difference of more than two orders of magnitude in body weight); their diets range from planktivorous to predators of large fish and squid; their foraging habitats range from neritic to pelagic areas, there are species with small foraging ranges while others feed throughout the whole circumpolar regions; some are divers and some forage at the sea surface; some seabirds are resident species (at a spatial mesoscale) whereas others are trans-equatorial migrators, which travel large distances across several oceanographic systems. With this variability in life history strategies and ecology, we should expect that the impacts of climate on seabird ecology to vary across ecological parameters and species that are impacted by climate variation. For instance, Kitaysky and Golubova (2000) showed that climate change differentially influenced reproductive performance of sympatric alcid species depending on their foraging strategy (e.g., planktivorous vs. piscivorous). Other studies have also addressed the influence of environmental variation in some seabird communities and the specific effects on each species relative to their particular ecology (Sydeman et al., 2001; Sabarros et al., 2012). Even for the same species in different studies, results are not always similar (see Table 1), suggesting differences among populations (Tavecchia et al., 2008) or raising doubts about the suitability of selected climate indexes, the temporal window analyzed or the power of each data set to detect associations between climate and the seabird parameter of interest, especially when these associations are not statistically significant (Jenouvrier, 2013). For instance, some studies found that the influence of increased SST on adult survival was positive or negative depending on the study colony or the genetic morph (Harris et al., 2005; Reiertsen et al., 2012), and these are good examples of how little we still know about the mechanisms linking climate and vital rates (Forero et al., 2001). Finally, non-linear relationships between demographic parameters and climate indices can also result in differences between studies on the same species when different temporal windows are considered. For example, if adult survival is associated nonlinearly with a climate covariate that changes through time, then performing the same analysis during two different time windows may yield different results.

It would be interesting (though very challenging) to have a global review available to understand what species and populations are more sensitive to climate variability, how important extreme climate events can be, how important a role intrinsic individual and state attributes (such as age, sex, breeding state, and physical condition) are playing, what temporal and 
Table 1 | Studies assessing the effects of climate on seabird adult survival.

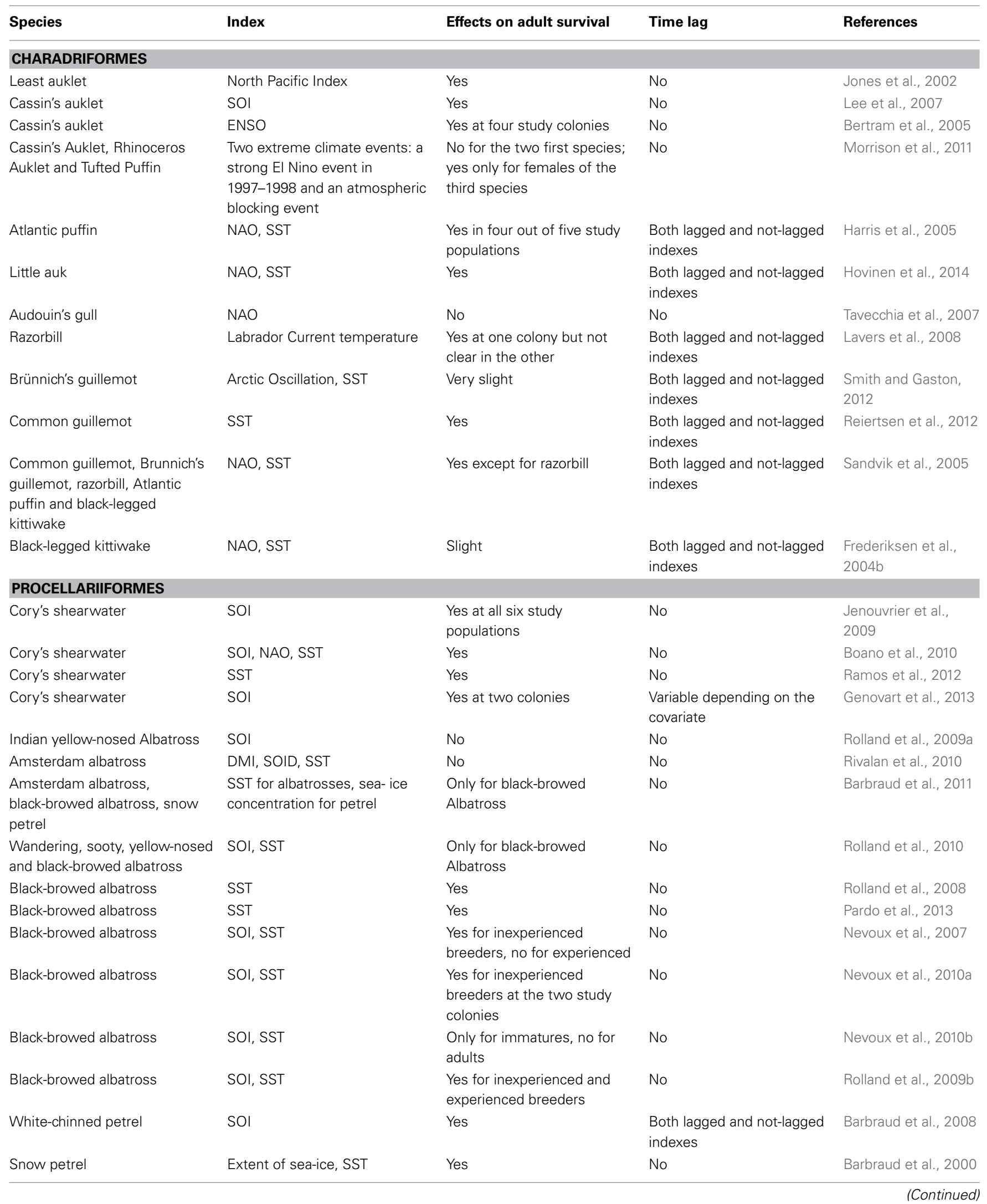


Table 1 | Continued

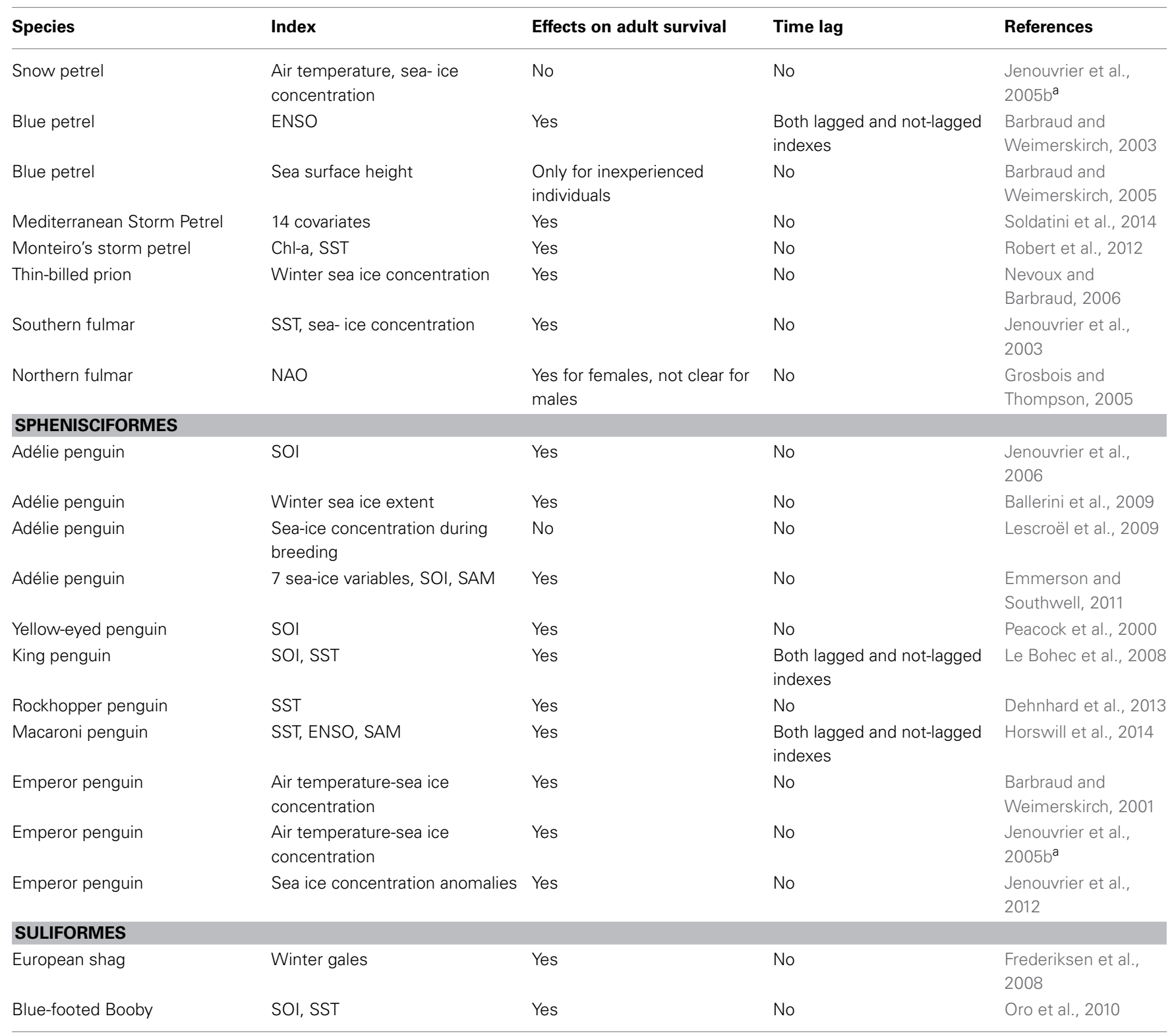

SOI, Southern oscillation index; NAO, North Atlantic oscillation index; DMI, dipole mode index; SAM, southern annular mode; SOID, Southern Indian Ocean dipole; SST, sea surface temperature.

${ }^{a}$ This study is duplicated because included two species of different orders.

spatial scales are most important, and how other biological processes (such as density-dependence, interference competition or predation) interact with climate (see also below). For instance, Ezard et al. (2007) suggested that to avoid drawing incorrect conclusions regarding variability in demographic or ecological parameters (such as breeding phenology) and/or the factors responsible for these perceived changes, researchers need to be sure and control for strong inherent sources of variation, such as age. These authors had a very detailed demographic data-set that is not always available in conventional studies, but these types of confounding biotic factors (i.e., age, sex) that should be taken into account when studying the effect of climate on seabird populations. An increasing number of studies showed that the effects of climate factors or pollutants on demographic parameters are state dependent (Nevoux et al., 2010a; Goutte et al., 2014). This also matches with life history theory since energetic costs and metabolism differ between breeding and nonbreeding individuals, which may in turn affect their demographic performance.

Another open question on climate-seabird research might be: is survival of larger seabirds (such as albatrosses) less sensitive to climate variability than survival of smaller species such as storm petrels? Larger species tend to have higher survival than smaller species (Weimerskirch, 2002), so environmental 
canalization (Gaillard and Yoccoz, 2004), i.e., the process of buffering environmental stochasticity should be stronger in the former than in the later. However, a qualitative look at available results is not so clear (see Table 1), maybe because biological reasons (e.g., life-history pressures, type of foraging habitat, noise from other processes such as intra-guild predation, competition, anthropogenic impacts) or because of methodological biases (increase of survival estimates through time due to appearance of more reliable statistical tools, Weimerskirch, 2002) or differential criteria to select climate indexes. It seems that there is no association between adult survival and body mass in Procellariiformes when phylogeny is taken into account in a capture-recapture modeling framework (Abadi et al., 2014); this may also explain the discrepancies found in several studies (Table 1), although this remains to be investigated in other seabird families.

When assessing the global impact of climate on seabirds, it should also be important to include the potential effects of breeding habitat loss or gain (typical of Arctic and Antarctic seabirds, but also among ground coastal nesting seabirds due to sea level rise), and the additive effects of anthropogenic impacts (mainly fisheries and direct harvesting, but also invasive species and pollutants) (Barbraud et al., 2012; Lewison et al., 2012; Goutte et al., 2013). To have some universal and comparable measure of the impact of climate on different species and populations, Jenouvrier (2013) proposed the use of a thorough new index, the "population robustness to climate change," together with retrospective and prospective analysis of population models.

Another gap of the association between seabirds and climate is the low number of studies on tropical seabird species. Most of seabird-climate studies have been conducted in temperate or polar marine ecosystems, whose functioning is different from tropical regions, where many seabirds occur with often poor conservation status. Future studies should thus attempt understanding tropical seabird ecology and demography and the effects of climate if we want to have better understanding of seabird climate relationships.

\section{THE IMPORTANCE OF SUITABLE TEMPORAL AND SPATIAL SCALES}

The use of oceanographic indexes to test the influence of climate on seabird ecology has been quite common (Sydeman et al., 2012), and mainly covered three spatial scales: some of them were more local (mainly climate around the breeding sites such as sea surface temperature, wind speed, air temperature, sea level pressure), some other were more regional (e.g., the Western Mediterranean Oscillation index WeMOi), whereas other indexes were more global such as El Niño-Southern Oscillation index (ENSO), Southern Oscillation index (SOI), the Southern Annular Mode (SAM), or the North Atlantic Oscillation index (NAO). The use of different spatial scales is not clearly justified in all studies (e.g., Soldatini et al., 2014) and an understanding of the spatial use of marine habitat made by each species in each period of the life cycle is essential to test appropriate hypotheses on the effect of climate on seabird ecology (Frederiksen et al., 2004a; Scott et al., 2006). To that end, the improvement of technology in recent decades (e.g., Burger and Shaffer, 2008; Wakefield et al.,
2009) has allowed researchers to increase their knowledge about migration routes (e.g., Guilford et al., 2009; Egevang et al., 2010), wintering areas (González-Solís et al., 2007; Frederiksen et al., 2012) and foraging areas also during reproduction (Gremillet et al., 2004; Guilford et al., 2008) and apply oceanographic indices at more appropriate temporal and spatial scales (Duffy, 1993; Weimerskirch et al., 2012).

Regarding the temporal window of the climate indexes used in each study, even though it has also been explained in most cases, it is not always coincident among studies either. This does not nullify the results of each individual study, but makes it harder to develop any common pattern from retrospective studies that encompass completely different snapshots in time. This is particularly worrying when analyzing survival, because this is the most sensitive parameter for seabird population dynamics, and it is crucial to understand what period of the whole year is more critically affecting this parameter. Some studies used only the temporal window of the breeding season (implying that conditions during breeding are more important for survival than conditions during winter, maybe through the costs of reproduction, what is against the expectations of life-history theory in long-lived organisms capable of reducing breeding effort in a given season if survival is threatened), whereas others used only climate conditions during winter (assuming that most mortality occurs in this period, Harris et al., 2005; Genovart et al., 2013), during the two periods separately (e.g., Barbraud and Weimerskirch, 2003) or even during the whole year as an integration of all year-round variability (Gordo et al., 2011). The temporal scale also defines the difference between weather and climate: the former consists of short-term (minutes to months) changes in the atmosphere, whereas the later is the average of weather over time and space. Some weather events (such as strong storms and tsunamis, Viera et al., 2006; Sherley et al., 2012) are not necessarily correlated with climate indexes and can introduce some noise when analysing their potential association with some ecological parameters, particularly short-term processes such as reproduction and hence breeding success (Schreiber, 2002).

In general, researchers need to be very careful to present results and conclusions, particularly from retrospective observational studies, because the study design and analytical approach used must be appropriate to properly answer research questions of interest. This is true for any spatial and temporal scales used, and positive results do not necessarily ensure that the index tested is the one explaining the most variance or alternatively that there is no effect on the parameter analyzed when negative results are reported. Little is known about the frequency of negative results that do not ever get published but the potential bias against these studies by journal reviewers and editors might bias a metaanalysis or any general review of the global effects of climate on seabirds (Sydeman et al., 2012). A general recommendation to properly select the most suitable indices at both temporal and spatial scales would be first partitioning the life cycle into breeding and non-breeding seasons, and then researchers should identify the foraging ranges used by the study species in each of those seasons and test for climate effects over the corresponding spatial scales. 


\section{THE MECHANISMS LINKING CLIMATE VARIATION TO SEABIRD POPULATION CHANGE}

Since most climate studies are based upon correlational evidence, the mechanistic processes linking climate variation to seabird ecology remain in most cases unclear, especially when global indexes are used (e.g., Breton et al., 2008; Sydeman et al., 2009). Typically, the first parameters to be affected when environmental conditions change are reproductive success because climate influence oceanographic conditions and food available for breeding, which is the main driver of fertility in the absence of predation (Oro et al., 1999; Schreiber and Burger, 2002; Frederiksen et al., 2006). Even though population change in seabirds is in theory less sensitive to changes in breeding success, this parameter, which influence recruitment rates, is often the vital rate that exhibits the most variation and it certainly constitutes an important factor that can affect population fluctuations. Sometimes the association between climate and breeding success is either direct in the form of heat strokes and catastrophic events such as volcanic eruptions, gales or tsunamis (Viera et al., 2006; Finkelstein et al., 2010; Sherley et al., 2012), or indirect, i.e., mediated by parasitism or diseases (Gaston et al., 2002; Cooper et al., 2009; Rolland et al., 2009a). That association should be strong in seabirds, because they are long-lived organisms and selection pressures have shaped conservatism in the energy devoted to reproduction: when environment is harsh, individuals invest less or may refrain from breeding and very low breeding success or even failures are commonly recorded for a number of species (La Cock, 1986; Frederiksen et al., 2006). However, there are other drivers that influence breeding success such as predation, food subsidies obtained from anthropogenic activities (mainly fisheries) and stochasticity in the links between climate and food-webs (Oro et al., 1996; Regehr and Montevecchi, 1997; Frederiksen et al., 2006).

The same correlation nature of studies linking climate variability with adult survival hinders the mechanisms involved, which are far from being well understood. This is particularly true when the process invoked is food availability through bottomup control in food webs, because at the population level, adults should not jeopardize their own survival (i.e., the most conservative parameter in long-lived organism) when environmental conditions are bad and trade-offs such as survival in lieu of reproduction should be observed (but see Olsson and van der Jeugd, 2002; Oro and Furness, 2002). Studies suggesting direct mortality caused by harsh marine conditions during winter (e.g., gales, hurricanes) (Frederiksen et al., 2008; Boano et al., 2010; Genovart et al., 2013) are clearer examples of the potential mechanisms linking climate and survival. Population fluctuations should be more sensitive to changes in adult survival in accordance with the theory of life-histories and the evolutionary canalization of adult survival, but this association is not always clear (Harris et al., 2005).

In general, the mechanisms involved in the association between climate and vital rates (e.g., breeding success, survival, recruitment, dispersal) can be associated directly with climate (extreme values of temperature, precipitation, winds) or indirectly, through climate effects on a critical resource (e.g., food, nest sites, wintering grounds) or an interacting biological component of the ecosystem (e.g., parasites, predators). Indirect effects are often harder to distinguish in that association because the complex nature of biological interaction in food webs.

In addition, time lags in climate indexes relative to survival and population change, for example, appear reasonable when climate effects on adult survival are mediated by the food-web, because seabirds are top-predators, and some delay between climate, physical forcing and a large part of the food chain is to be expected (Thompson and Ollason, 2001; Arnott and Ruxton, 2002; Lloret et al., 2004; Martín et al., 2012). Furthermore, this delay may depend on the species, with some taxa feeding on relatively low trophic levels (e.g., fish larvae), whereas some species feed on higher food web prey (e.g., squid). However, the range of timelags recorded between climate and adult survival has been variable among studies or not tested at all (Table 1, see also Jenouvrier, 2013) and the confounding effects of time, cohort and age on survival and recruitment sometimes make it difficult to assess the reliability of results. Correlations between climate covariates and population fluctuations are also analyzed either with time lags or without lagged associations. In the former case, researchers assume that those covariates influence mainly fertility and the effects on population numbers are reflected some years later, owing that seabirds do not reach sexual maturity for several years until recruitment (Cook et al., 2014). In some other cases, climate covariates of the previous year were tested, and researchers assume that conditions prior to breeding were more important by influencing adult survival, breeding propensity and immigration (Jenouvrier et al., 2003; Frederiksen et al., 2008; Irons et al., 2008; Devney et al., 2009; Lauria et al., 2012). The absence of time lag in the response of seabirds to climate variability may be reasonable in some situations, even when the process invoked is food availability, because availability of food depends on its abundance, accessibility, and distribution, which can be directly influenced by climate. Jenouvrier et al. (2005a) found that climate may have a direct or a lagged effect on population dynamics depending on environmental stochastic conditions. Some studies showed that climate have a simultaneous effects both direct and lagged because each demographic parameter are affected differently by climate (Erikstad et al., 2013; Sandvik et al., 2014). Finally, the existence of non-linear relationships between climate and seabird ecological parameters has seldom been explored (e.g., Durant et al., 2004; Jenouvrier et al., 2005a; Ballerini et al., 2009; Regular et al., 2009), despite the importance of identifying tipping points and thresholds when buffering capacity (i.e., both behavioral and demographic) is overcome.

\section{PREDICTING THE FUTURE IMPACTS OF CLIMATE ON SEABIRDS}

What is our capacity to forecast the effects of climate change on seabird abundance, distribution and viability? Several now relatively old papers anticipated the importance of predicting how climate would affect marine food webs and top-marine predators (Crawford, 1991). However, climate is just one driver among environmental-change agents and our ability to modify climate, compared to some other components of environmental change (e.g., pollutants, habitat fragmentation, fisheries interactions), is very limited. In addition, climate has a strong inertia, so it is 
difficult to apply conservation and management actions even if we are able to build reliable predictions for some extreme cases with detailed demographic information (e.g., some penguin, petrel and albatross species typical of Polar regions). Predictions are challenging because they rely on models built using retrospective data (i.e., "past" relationships) and thus include considerable uncertainty regarding future trajectories (Hulme, 2005; Sutherland, 2006). In addition, the best predictive models rely on large amounts of high quality demographic data, and sophisticated quantitative approaches. Yet, generating general predictions is difficult because of the inherent ecological variability amongst species, ecosystems (Chambers et al., 2011) and even among individuals (Lescroël et al., 2009, 2010; Lescroel et al., 2014) and populations (Tavecchia et al., 2008; Dias et al., 2010). These predictions, if they are local, can also be biased by dispersal processes (e.g., Woehler et al., 2014), because seabirds are very vagile, even species considered as highly philopatric (Genovart et al., 2007). Despite those constraints, population models together with tools for time-series analysis have yielded very promising results when long-term data sets and detailed estimations of demographic parameters were available (Jenouvrier et al., 2009, 2012, 2005a). Thus, research on the effects of climate on seabirds (or on any other organism and ecosystem) should be focused to building solid scientific evidence on predicted rates of population change, meta-population dynamics, and changes in species distribution given the present rates of warming (Sydeman et al., 2012). Testing hypotheses about the effects of climate on seabird ecology (e.g., diet, behavior, and phenology) is a first step toward making predictions regarding climate effects on population trajectories and to understanding the mechanisms linking patterns and processes, but this is just the first step. In general, we should move to a research devoted more toward forecasting the effects of global change (not only climate, but considering the synergetic effects of several agents of global change (e.g., Votier et al., 2008b; Finkelstein et al., 2010; Rolland et al., 2010; Lebreton, 2011), and to offer evidence that can help managers develop a roadmap of conservation actions (Jenouvrier, 2013). However, we need to collect the foundational information regarding links between demographics and climate, and the mechanisms that link them as we must have robust estimates of vital rates to build predictive models, and this constitutes a big challenge. In general, there is more potential to manage the impacts of other global change agents such as overharvesting (Jahncke et al., 2004; Becker and Beissinger, 2006), bycatch in fisheries (Bunce et al., 2002; Barbraud et al., 2008; Rolland et al., 2008; Ramos et al., 2012), habitat deterioration (Lindenmayer and Fischer, 2013), pollution (Croxall et al., 2012) or invasive species (Nogales et al., 2004; Ruffino et al., 2009; Major et al., 2013) than there is for managing climate (Rogelj et al., 2013), so this can be an indirect way of battling the impacts of climate warming.

Finally, population predictions must take into account the resilience of species to environmental change including extreme events, which are predicted to increase in frequency. For example, Hass et al. (2012) forecasts the impact of increasing hurricanes on the viability of the already endangered black-capped petrel Pterodroma hasitata, and predicted that this increase in hurricane frequency could nearly double the expected number of wrecked petrels over the next century, placing the species at greater risk of extinction by acting upon already much reduced populations due to human action (e.g., harvesting, bycatch, loss of breeding habitat). In addition Gremillet et al. (2012) showed that foraging behavior plasticity in little auks Alle alle maintained fitness levels across a wide range of sea surface temperatures, which may buffer them against at least the initial impacts of climate change. Several ecological parameters (e.g., vital rates, distribution, and foraging ranges) have been observed to shift as a result of changes in climate in several seabird species, but relatively little is known about the potential for changes in other demographic mechanisms to buffer these shifts. I can hypothesize that changes in recruitment rates, breeding propensity and increased fertility, as well as the role of immigration in source-sink systems at local population level, all have the potential to offset potential declines in survival for example, in relation to climate change. Some of these compensatory mechanisms have been already found in harvested populations of fish and ungulates (Lebreton, 2005; Servanty et al., 2011).

At the scale of geological times, seabirds have a long evolutionary history. Bone remains of a Phaeton tropicbird have been recently found in Morocco preserved from the Ypresian Age, in the lower Eocene, ca. $48 \times 10^{6}$ years ago (Bourdon et al., 2008). In geological- time scales, seabirds have experienced changes in climate, including warming and cooling periods, and extreme events. The previous interglacial period $\left(1.2-1.3^{*} 10^{5}\right.$ years $\left.\mathrm{BP}\right)$ was substantially warmer than the present one; about $2^{\circ} \mathrm{C}$ in the North Temperate Zone and $5^{\circ} \mathrm{C}$ in the Arctic, and it may have been the warmest period since the onset of the Pliocene (Fedorov et al., 2013). Some species have likely shown more plasticity to adapt to such changes and to anthropogenic factors acting in synergy with climate change, and we have to identify what species would be more sensitive to the current rate of climate change. A major difference between the so-called Anthropocene with previous geological periods is major habitat alteration due to the growth of human population (breeding habitat destruction, introduced predators, pollutants) with these factors acting in synergy with climate. Therefore, plasticity may be not enough to adapt to climate change given these additional factors for which many seabird species were not previously exposed and selected for. For instance, Igual et al. (2007) showed that Cory's shearwaters, due to their limited behavioral plasticity and heavy evolutionary loads, did not perceive the presence of invasive predators signaling differences in predation risk and in turn of breeding success.

Climate has in itself the features of a paradigmatic complex system: emergent properties that cannot be explained by the sum of its components. So the study of its influence on seabird ecology is far from being straightforward because climate has many emergent properties that cannot be explained solely by the sum if its own components, to a large extent because of its random structure, and additionally because many other factors can be involved, including extrinsic (e.g., predators in the case of small and medium-sized species, prey density, competition) and intrinsic (e.g., density-dependence, age-structure, sex) factors. 


\section{ACKNOWLEDGMENTS}

I thank Morten Frederiksen for inviting me to participate in this research topic, and to Alejandro Martínez-Abraín, Katie Dugger, and Christophe Barbraud for their valuable and helpful comments and corrections. Michelle Lynn Johnson gently improved the English. My research is funded by the Balearic Regional Government (FEDER programme) and the Spanish Ministry of Economy (ref. CGL2013-42203-R).

\section{REFERENCES}

Abadi, F., Barbraud, C., Besson, D., Bried, J., Crochet, P.-A., Delord, K., et al. (2014). Importance of accounting for phylogenetic dependence in multi-species mark-recapture studies. Ecol. Model. 273, 236-241. doi: 10.1016/j.ecolmodel.2013.11.017

Abrams, R. (1985). Environmental determinants of pelagic seabird distribution in the African sector of the southern-ocean. J. Biogeogr. 12, 473-492. doi: $10.2307 / 2844955$

Ainley, D. G., Sydeman, W. J., Hatch, S. A., and Wilson, U. W. (1994). Seabird population trends along the west coast of North America: causes and the extent of regional concordance. Stud. Avian Biol. 15, 119-133.

Arnott, S. A., and Ruxton, G. D. (2002). Sandeel recruitment in the north sea: demographic, climatic and trophic effects. Mar. Ecol. Prog. Ser. 238, 199-210. doi: 10.3354/meps238199

Ballerini, T., Tavecchia, G., Olmastroni, S., Pezzo, F., and Focardi, S. (2009). Nonlinear effects of winter sea ice on the survival probabilities of Adélie penguins. Oecologia 161, 253-265. doi: 10.1007/s00442-009-1387-9

Barbraud, C., Marteau, C., Ridoux, V., Delord, K., and Weimerskirch, H. (2008). Demographic response of a population of white-chinned petrels Procellaria aequinoctialis to climate and longline fishery bycatch. J. Appl. Ecol. 45, 1460-1467. doi: 10.1111/j.1365-2664.2008.01537.x

Barbraud, C., Rivalan, P., Inchausti, P., Nevoux, M., Rolland, V., and Weimerskirch, H. (2011). Contrasted demographic responses facing future climate change in Southern Ocean seabirds. J. Anim. Ecol. 80, 89-100. doi: 10.1111/j.13652656.2010.01752.x

Barbraud, C., Rolland, V., Jenouvrier, S., Nevoux, M., Delord, K., and Weimerskirch, H. (2012). Effects of climate change and fisheries bycatch on Southern Ocean seabirds?: a review. Mar. Ecol. Prog. Ser. 454, 285-307. doi: 10.3354/meps09616

Barbraud, C., and Weimerskirch, H. (2001). Emperor penguins and climate change. Nature 411, 183-186. doi: 10.1038/35075554

Barbraud, C., and Weimerskirch, H. (2003). Climate and density shape population dynamics of a marine top predator. Proc. R. Soc. Lond. B Biol. Sci. 270, 2111-2116. doi: 10.1098/rspb.2003.2488

Barbraud, C., and Weimerskirch, H. (2005). Environmental conditions and breeding experience affect costs of reproduction in blue petrels. Ecology 86, 682-692. doi: 10.1890/04-0075

Barbraud, C., Weimerskirch, H., Guinet, C., and Jouventin, P. (2000). Effect of sea-ice extent on adult survival of an Antarctic top predator: the snow petrel Pagodroma nivea. Oecologia 125, 483-488. doi: 10.1007/s0044200 00481

Becker, B. H., and Beissinger, S. R. (2006). Centennial decline in the trophic level of an endangered seabird after Fisheries decline. Conserv. Biol. 20, 470-479. doi: 10.1111/j.1523-1739.2006.00379.x

Bertram, D. F., Harfenist, A., and Smith, B. D. (2005). Ocean climate and El Nino impacts on survival of Cassin's Auklets from upwelling and downwelling domains of British Columbia. Can. J. Fish. Aquat. Sci. 62, 2841-2853. doi: 10.1139/F05-190

Blomqvist, S., and Peterz, M. (1984). Cyclones and pelagic seabird movements. Mar. Ecol. Prog. Ser. 20, 85-92. doi: 10.3354/meps020085

Boano, G., Brichetti, P., and Foschi, U. F. (2010). “La Niña”-driven Atlantic storms affect winter survival of Mediterranean Cory's Shearwaters. Ital. J. Zool. 77, 460-468. doi: 10.1080/11250000903469017

Bourdon, E., Amaghzaz, M., and Bouya, B. (2008). A new seabird (Aves, cf. Phaethontidae) from the Lower Eocene phosphates of Morocco. Geobios 41, 455-459. doi: 10.1016/j.geobios.2007.11.002

Breton, A. R., Kildaw, S. D., Murra, K., and Buck, C. L. (2008). Multilevel models reveal no cohort-level variation in time spent foraging to account for a collapse in kittiwake (Rissa tridactyla) breeding success. Ecol. Model. 212, 233-243. doi: 10.1016/j.ecolmodel.2007.10.003

Brown, R. G. B. (1991). "Marine birds and climatic warming in the northwest Atlantic," in Studies of High Latitude Seabirds. 1. Behavioural, Energetic and Oceanographic Aspects of Seabird Feeding Ecology. Canadian Wildlife Service Occasional Paper No. 68, eds W. A. Montevecchi and A. J. Gaston (Ottawa: Canadian Wildlife Service), 49-54.

Bunce, A., Norman, F. I., Brothers, N., and Gales, R. (2002). Long-term trends in the Australasian gannet (Morus serrator) population in Australia: the effect of climate change and commercial fisheries. Mar. Biol. 141, 263-269. doi: 10.1007/s00227-002-0838-1

Burger, A. E., and Shaffer, S. A. (2008). Perspectives in ornithology application of tracking and data-logging technology in research and conservation of seabirds. Auk 125, 253-264. doi: 10.1525/auk.2008.1408

Burger, J. (1990). Seabirds, tropical biology and global warming - are we missing the Ark. Colon. Waterbirds 13, 81-84. doi: 10.2307/1521571

Burthe, S. J., Wanless, S., Newell, M. A., Butler, A., and Daunt, F. (2014). Assessing the vulnerability of the marine bird community in the western North Sea to climate change and other anthropogenic impacts. Mar. Ecol. Prog. Ser. 507, 277-295. doi: 10.3354/meps10849

Bustnes, J. O., Anker-Nilssen, T., Erikstad, K. E., Lorentsen, S.-H., and Systad, G. H. (2013). Changes in the Norwegian breeding population of European shag correlate with forage fish and climate. Mar. Ecol. Prog. Ser. 489, 235-244. doi: 10.3354/meps 10440

Chambers, L. E., Devney, C. A., Congdon, B. C., Dunlop, N., Woehler, E. J., and Dann, P. (2011). Observed and predicted effects of climate on Australian seabirds. Emu 111, 235-251. doi: 10.1071/MU10033

Cook, A. S. C. P., Dadam, D., Mitchell, I., Ross-Smith, V. H., and Robinson, R. A. (2014). Indicators of seabird reproductive performance demonstrate the impact of commercial fisheries on seabird populations in the North Sea. Ecol. Indic. 38, 1-11. doi: 10.1016/j.ecolind.2013.10.027

Cooper, J., Crawford, R. J. M., De Villiers, M. S., Dyer, B. M., Hofmeyr, G. J. G., and Jonker, A. (2009). Disease outbreaks among penguins at sub-Antarctic Marion Island: a conservation concern. Mar. Ornithol. 37, 193-196.

Crawford, R. (1991). Factors influencing population trends of some abundant vertebrates in Sardine-Rich coastal ecosystems. South Afr. J. Mar. Sci. 10, 365-381. doi: 10.2989/02577619109504645

Croxall, J. P., Butchart, S. H. M., Lascelles, B., Stattersfield, A. J., Sullivan, B., Symes, A., et al. (2012). Seabird conservation status, threats and priority actions: a global assessment. Bird Conserv. Int. 22, 1-34. doi: 10.1017/S0959270912000020

Dehnhard, N., Poisbleau, M., Demongin, L., Ludynia, K., Lecoq, M., Masello, J. F., et al. (2013). Survival of Rockhopper penguins in times of global climate change. Aquat. Conserv. Mar. Freshwater Ecosyst. 23, 777-789. doi: 10.1002/aqc.2331

Devney, C. A., Short, M., and Congdon, B. C. (2009). Sensitivity of tropical seabirds to El Niño precursors. Ecology 90, 1175-1183. doi: 10.1890/08-0634.1

Dias, M. P., Granadeiro, J. P., Phillips, R. A., Alonso, H., and Catry, P. (2010). Breaking the routine: individual Cory's shearwaters shift winter destinations between hemispheres and across ocean basins. Proc. R. Soc. B Biol. Sci. 278, 1786-1793. doi: 10.1098/rspb.2010.2114

Duffy, D. C. (1993). "Stalking the Southern Oscillation: environmental uncertainty, climate change, and North Pacific seabirds," in The Status, Ecology, and Conservation of Marine Birds of the North Pacific, eds K. Vermeer, K. T. Briggs, K. H. Morgan, and D. Siegel-Causey (Ottawa, ON: Can. Wildl. Serv. Spec. Publ.), 61-67.

Durant, J. M., Stenseth, N. C., Anker-Nilssen, T., Harris, M. P., Thompson, P. M., and Wanless, S. (2004). "Marine birds and climate fluctuation in North Atlantic," in Marine Ecosystems and Climate Variation: the North Atlantic, eds N. C. Stenseth, G. Ottersen, J. W. Hurrell, and A. Belgrano (Oxford: Oxford University Press), 95-105.

Egevang, C., Stenhouse, I. J., Phillips, R. A., Petersen, A., Fox, J. W., and Silk, J. R. D. (2010). Tracking of Arctic terns Sterna paradisaea reveals longest animal migration. Proc. Natl. Acad. Sci. U.S.A. 107, 2078-2081. doi: 10.1073/pnas.0909493107

Emmerson, L., and Southwell, C. (2011). Adélie penguin survival: age structure, temporal variability and environmental influences. Oecologia 167, 951-965. doi: 10.1007/s00442-011-2044-7

Erikstad, K. E., Reiertsen, T. K., Barrett, R. T., Vikeb, F., and Sandvik, H. (2013). Seabird-fish interactions: the fall and rise of a common guillemot Uria aalge population. Mar. Ecol. Prog. Ser. 475, 267-276. doi: 10.3354/meps10084 
Ezard, T. H. G., Becker, P. H., and Coulson, T. (2007). Correlations between age, phenotype, and individual contribution to population growth in common terns. Ecology 88, 2496-2504. doi: 10.1890/06-2020.1

Fedorov, A. V., Brierley, C. M., Lawrence, K. T., Liu, Z., Dekens, P. S., and Ravelo, A. C. (2013). Patterns and mechanisms of early Pliocene warmth. Nature 496 43-49. doi: 10.1038/nature12003

Finkelstein, M. E., Wolf, S., Goldman, M., Doak, D. F., Sievert, P. R., Balogh, G., et al. (2010). The anatomy of a (potential) disaster: Volcanoes, behavior, and population viability of the short-tailed albatross (Phoebastria albatrus). Biol. Conserv. 143, 321-331. doi: 10.1016/j.biocon.2009.10.013

Forcada, J., and Trathan, P. N. (2009). Penguin responses to climate change in the Southern Ocean. Glob. Change Biol. 15, 1618-1630. doi: 10.1111/j.13652486.2009.01909.x

Forcada, J., Trathan, P. N., and Murphy, E. J. (2008). Life history buffering in Antarctic mammals and birds against changing patterns of climate and environmental variation. Glob. Change Biol. 14, 2473-2488. doi: 10.1111/j.13652486.2008.01678.x

Forero, M. G., Tella, J. L., and Oro, D. (2001). Annual survival rates of adult Rednecked Nightjars Caprimulgus ruficollis. Ibis 143, 273-277. doi: 10.1111/j.1474919X.2001.tb04483.x

Frederiksen, M., Daunt, F., Harris, M. P., and Wanless, S. (2008). The demographic impact of extreme events: stochastic weather drives survival and population dynamics in a long-lived seabird. J. Anim. Ecol. 77, 1020-1029. doi: 10.1111/j.1365-2656.2008.01422.x

Frederiksen, M., Edwards, M., Richardson, A. J., Halliday, N. C., and Wanless, S. (2006). From plankton to top predators: bottom-up control of a marine food web across four trophic levels. J. Anim. Ecol. 75, 1259-1268. doi: 10.1111/j.13652656.2006.01148.x

Frederiksen, M., Harris, M. P., Daunt, F., Rothery, P., and Wanless, S. (2004a). Scaledependent climate signals drive breeding phenology of three seabird species. Glob. Change Biol. 10, 1214-1221. doi: 10.1111/j.1529-8817.2003.00794.x

Frederiksen, M., Moe, B., Daunt, F., Phillips, R. A., Barrett, R. T., Bogdanova, M. I., et al. (2012). Multicolony tracking reveals the winter distribution of a pelagic seabird on an ocean basin scale. Divers. Distrib. 18, 530-542. doi: 10.1111/j.1472-4642.2011.00864.x

Frederiksen, M., Wanless, S., Harris, M. P., Rothery, P., and Wilson, L. J. (2004b). The role of industrial fisheries and oceanographic change in the decline of North Sea black-legged kittiwakes. J. Appl. Ecol. 41, 1129-1139. doi: 10.1111/j.00218901.2004.00966.x

Gaillard, J.-M., and Yoccoz, N. G. (2004). Temporal variation in survival of mammals: a case of environmental canalization. Ecology 84, 3294-3306. doi: 10.1890/02-0409

Gaston, A. J., Hipfner, J. M., and Campbell, D. (2002). Heat and mosquitoes cause breeding failures and adult mortality in an Arctic-nesting seabird. Ibis 144 185-191. doi: 10.1046/j.1474-919X.2002.00038.x

Genovart, M., Oro, D., Juste, J., and Bertorelle, G. (2007). What genetics tell us about the conservation of the critically endangered Balearic Shearwater? Biol. Conserv. 137, 283-293. doi: 10.1016/j.biocon.2007.02.016

Genovart, M., Sanz-Aguilar, A., Fernández-Chacón, A., Igual, J. M., Pradel, R. Forero, M. G., et al. (2013). Contrasting effects of climatic variability on the demography of a trans-equatorial migratory seabird. J. Anim. Ecol. 82, 121-130. doi: 10.1111/j.1365-2656.2012.02015.x

Glantz, M. H. (2001). Currents of Change: Impacts of El Niño and La Niña on Climate and Society. Cambridge: Cambridge University Press.

González-Solís, J., Croxall, J. P., Oro, D., and Ruiz, X. (2007). Trans-equatorial migration and mixing in the wintering areas of a pelagic seabird. Front. Ecol. Environ. 5, 297-301. doi: 10.1890/1540-9295(2007)5[297:TMAMIT]2.0.CO;2

Gordo, O., Barriocanal, C., and Robson, D. (2011). "Ecological impacts of the North Atlantic Oscillation (NAO) in mediterranean ecosystems," in Hydrological, Socioeconomic and Ecological Impacts of the North Atlantic Oscillation in the Mediterranean Region Advances in Global Change Research, eds S. M. Vicente-Serrano and R. M. Trigo (Dordrecht: Springer), 153-170. doi: 10.1007/978-94-007-1372-7_11

Goutte, A., Barbraud, C., Meillère, A., Carravieri, A., Bustamante, P., Labadie, P., et al. (2014). Demographic consequences of heavy metals and persistent organic pollutants in a vulnerable long-lived bird, the wandering albatross. Proc. R. Soc. B Biol. Sci. 281, 3313. doi: 10.1098/rspb.2013.3313

Goutte, A., Bustamante, P., Barbraud, C., Delord, K., Weimerskirch, H., and Chastel, O. (2013). Demographic responses to mercury exposure in two closely related Antarctic top predators. Ecology 95, 1075-1086. doi: 10.1890/131229.1

Graybill, M. R., and Hodder, J. (1985). The Biological Response. Effects of the 1982-83 El Niño on Reproduction of Six Species of Seabirds in Oregon. Seattle, WA: Washington Sea Grant Program.

Green, J. L., Hastings, A., Arzberger, P., Ayala, F. J., Cottingham, K. L., Cuddington, K., et al. (2005). Complexity in ecology and conservation: mathematical, statistical, and computational challenges. Bioscience 55, 501-510. doi: 10.1641/00063568(2005)055[0501:CIEACM]2.0.CO;2

Gremillet, D., Dell'omo, G., Ryan, P. G., Peters, G., Ropert-Coudert, Y., and Weeks, S. J. (2004). Offshore diplomacy, or how seabirds mitigate intra-specific competition: a case study based on GPS tracking of Cape gannets from neighbouring colonies. Mar. Ecol. Prog. Ser. 268, 265-279.

Gremillet, D., Welcker, J., Karnovsky, N. J., Walkusz, W., Hall, M. E., Fort, J., et al. (2012). Little auks buffer the impact of current Arctic climate change. Mar. Ecol. Prog. Ser. 454, 197-206. doi: 10.3354/meps09590

Grosbois, V., Gimenez, O., Gaillard, J.-M., Pradel, R., Barbraud, C., Clobert, J., et al. (2008). Assessing the impact of climate variation on survival in vertebrate populations. Biol. Rev. 83, 357-399. doi: 10.1111/j.1469-185X.2008.00047.x

Grosbois, V., and Thompson, P. M. (2005). North Atlantic climate variation influences survival in adult fulmars. Oikos 109, 273-290. doi: 10.1111/j.00301299.2005.13774.x

Guilford, T. C., Meade, J., Freeman, R., Biro, D., Evans, T., Bonadonna, F., et al. (2008). GPS tracking of the foraging movements of Manx Shearwaters Puffinus puffinus breeding on Skomer Island, Wales. Ibis 150, 462-473. doi: 10.1111/j.1474-919X.2008.00805.x

Guilford, T., Meade, J., Willis, J., Phillips, R. A., Boyle, D., Roberts, S., et al. (2009). Migration and stopover in a small pelagic seabird, the Manx shearwater Puffinus puffinus: insights from machine learning. Proc. R. Soc. B Biol. Sci. 276, 1215-1223. doi: 10.1098/rspb.2008.1577

Guinet, C., Chastel, O., Koudil, M., Durbec, J. P., and Jouventin, P. (1998). Effects of warm sea-surface temperature anomalies on the blue petrel at the Kerguelen Islands. Proc. R. Soc. B Biol. Sci. 265, 1001-1006. doi: 10.1098/rspb.19 98.0390

Harris, M. P., Anker-Nilssen, T., McCleery, R. H., Erikstad, K. E., Shaw, D. N., and Grosbois, V. (2005). Effect of wintering area and climate on the survival of adult Atlantic puffins Fratercula arctica in the eastern Atlantic. Mar. Ecol. Prog. Ser. 297, 283-296. doi: 10.3354/meps 297283

Hass, T., Hyman, J., and Semmens, B. X. (2012). Climate change, heightened hurricane activity, and extinction risk for an endangered tropical seabird, the black-capped petrel Pterodroma hasitata. Mar. Ecol. Prog. Ser. 454, 251-261. doi: 10.3354/meps09723

Horswill, C., Matthiopoulos, J., Green, J. A., Meredith, M. P., Forcada, J., Peat, H., et al. (2014). Survival in Macaroni penguins and the relative importance of different drivers: individual traits, predation pressure and environmental variability. J. Anim. Ecol. 83, 1057-1067. doi: 10.1111/1365-2656.12229

Hovinen, J. E. H., Welcker, J., Descamps, S., Strøm, H., Jerstad, K., Berge, J., et al. (2014). Climate warming decreases the survival of the little auk (Alle alle), a high Arctic avian predator. Ecol. Evol. 4, 3127-3138. doi: 10.1002/ece3.1160

Hulme, P. E. (2005). Adapting to climate change: is there scope for ecological management in the face of a global threat? J. Appl. Ecol. 42, 784-794. doi: 10.1111/j.1365-2664.2005.01082.x

Hunt, G. L., Eppley, Z. A., and Schneider, D. C. (1986). Reproductive performance of seabirds: the importance of population and colony size. Auk 103, 306-317.

Igual, J. M., Forero, M. G., Gomez, T., and Oro, D. (2007). Can an introduced predator trigger an evolutionary trap in a colonial seabird? Biol. Conserv. 137, 189-196. doi: 10.1016/j.biocon.2007.02.003

Irons, D. B., Anker-Nilssen, T., Gaston, A. J., Byrd, G. V., Falk, K., Gilchrist, G., et al. (2008). Fluctuations in circumpolar seabird populations linked to climate oscillations. Glob. Change Biol. 14, 1455-1463. doi: 10.1111/j.13652486.2008.01581.x

Jahncke, J., Checkley, D. M., and Hunt, G. L. (2004). Trends in carbon flux to seabirds in the Peruvian upwelling system: effects of wind and fisheries on population regulation. Fish. Oceanogr. 13, 208-223. doi: 10.1111/j.13652419.2004.00283.x

Jenouvrier, S. (2013). Impacts of climate change on avian populations. Glob. Change Biol. 19, 2036-2057. doi: 10.1111/gcb.12195

Jenouvrier, S., Barbraud, C., Cazelles, B., and Weimerskirch, H. (2005a). Modelling population dynamics of seabirds: importance of the effects of climate 
fluctuations on breeding proportions. Oikos 108, 511-522. doi: 10.1111/j.00301299.2005.13351.x

Jenouvrier, S., Barbraud, C., and Weimerskirch, H. (2003). Effects of climate variability on the temporal population dynamics of southern fulmars. J. Anim. Ecol. 72, 576-587. doi: 10.1046/j.1365-2656.2003.00727.x

Jenouvrier, S., Barbraud, C., and Weimerskirch, H. (2005b). Long-term contrasted responses to climate of two Antarctic seabird species. Ecology 86, 2889-2903. doi: 10.1890/05-0514

Jenouvrier, S., Barbraud, C., and Weimerskirch, H. (2006). Sea ice affects the population dynamics of Adélie penguins in Terre Adélie. Polar Biol. 29, 413-423. doi: 10.1007/s00300-005-0073-6

Jenouvrier, S., Holland, M., Stroeve, J., Barbraud, C., Weimerskirch, H., Serreze, M., et al. (2012). Effects of climate change on an emperor penguin population: analysis of coupled demographic and climate models. Glob. Change Biol. 18, 2756-2770. doi: 10.1111/j.1365-2486.2012.02744.x

Jenouvrier, S., Thibault, J.-C., Viallefont, A., Vidals, P., Ristow, D., Mougin, J.-L., et al. (2009). Global climate patterns explain range-wide synchronicity in survival of a migratory seabird. Glob. Change Biol. 15, 268-279. doi: 10.1111/j.1365-2486.2008.01715.x

Jones, I. L., Hunter, F. M., and Robertson, G. J. (2002). Annual adult survival of Least Auklets (Aves, Alcidae) varies with large-scale climatic conditions of the North Pacific Ocean. Oecologia 133, 38-44. doi: 10.1007/s00442-002-0991-8

Kitaysky, A. S., and Golubova, E. G. (2000). Climate change causes contrasting trends in reproductive performance of planktivorous and piscivorous alcids. J. Anim. Ecol. 69, 248-262. doi: 10.1046/j.1365-2656.2000.00392.x

La Cock, G. D. L. (1986). The Southern Oscillation, environmental anomalies, and mortality of two Southern African seabirds. Clim. Change 8, 173-184. doi: 10.1007/BF00139753

Lauria, V., Attrill, M. J., Pinnegar, J. K., Brown, A., Edwards, M., and Votier, S. C. (2012). Influence of climate change and trophic coupling across four trophic levels in the Celtic Sea. PLoS ONE 7:e47408. doi: 10.1371/journal.pone.0047408

Lavers, J. L., Jones, I. L., Diamond, A. W., and Robertson, G. J. (2008). Annual survival of North American Razorbills (Alca torda) varies with ocean climate indices. Can. J. Zool. Rev. Can. Zool. 86, 51-61. doi: 10.1139/Z07-113

Le Bohec, C., Durant, J. M., Gauthier-Clerc, M., Stenseth, N. C., Park, Y.-H., Pradel, R., et al. (2008). King penguin population threatened by Southern Ocean warming. Proc. Natl. Acad. Sci. U.S.A. 105, 2493-2497. doi: 10.1073/pnas.0712031105

Lebreton, J.-D. (2005). Dynamical and statistical models for exploited populations. Aust. N.Z. J. Stat. 47, 49-63. doi: 10.1111/j.1467-842X.2005.00371.x

Lebreton, J.-D. (2011). The impact of global change on terrestrial Vertebrates. Comptes Rendus Biol. 334, 360-369. doi: 10.1016/j.crvi.2011.01.005

Lee, D. E., Nur, N., and Sydeman, W. J. (2007). Climate and demography of the planktivorous Cassin's auklet Ptychoramphus aleuticus off northern California: implications for population change. J. Anim. Ecol. 76, 337-347. doi: 10.1111/j.1365-2656.2007.01198.x

Lescroel, A., Ballard, G., Gremillet, D., Authier, M., and Ainley, D. G. (2014). Antarctic climate change: extreme events disrupt plastic phenotypic response in Adelie Penguins. PLoS ONE 9:e85291. doi: 10.1371/journal.pone.0085291

Lescroël, A., Ballard, G., Toniolo, V., Barton, K. J., Wilson, P. R., Lyver, P. O., et al. (2010). Working less to gain more: when breeding quality relates to foraging efficiency. Ecology 91, 2044-2055. doi: 10.1890/09-0766.1

Lescroël, A., Dugger, K. M., Ballard, G., and Ainley, D. G. (2009). Effects of individual quality, reproductive success and environmental variability on survival of a long-lived seabird. J. Anim. Ecol. 78, 798-806. doi: 10.1111/j.13652656.2009.01542.x

Lewison, R., Oro, D., Godley, B., Underhill, L., Bearhop, S., Wilson, R., et al. (2012). Research priorities for seabirds: improving conservation and management in the 21st century. Endanger. Species Res. 17, 93-121. doi: 10.3354/ esr00419

Lindenmayer, D. B., and Fischer, J. (2013). Habitat Fragmentation and Landscape Change: An Ecological and Conservation Synthesis. Washington, DC: Island Press.

Lloret, J., Palomera, I., Salat, J., and Sole, I. (2004). Impact of freshwater input and wind on landings of anchovy (Engraulis encrasicolus) and sardine (Sardina pilchardus) in shelf waters surrounding the Ebre (Ebro) River delta (northwestern Mediterranean). Fish. Oceanogr. 13, 102-110. doi: 10.1046/j.13652419.2003.00279.x

Lyver, P. O., Moller, H., and Thompson, C. (1999). Changes in sooty shearwater Puffinus griseus chick production and harvest precede ENSO events. Mar. Ecol. Prog. Ser. 188, 237-248. doi: 10.3354/meps188237
Major, H. L., Bond, A. L., Jones, I. L., and Eggleston, C. J. (2013). Stability of a seabird population in the presence of an introduced predator. Avian Conserv. Ecol. 8:2. doi: 10.5751/ACE-00564-080102

Martín, P., Sabatés, A., Lloret, J., and Martin-Vide, J. (2012). Climate modulation of fish populations: the role of the Western Mediterranean Oscillation (WeMO) in sardine (Sardina pilchardus) and anchovy (Engraulis encrasicolus) production in the north-western Mediterranean. Clim. Change 110, 925-939. doi: 10.1007/s10584-011-0091-z

Martínez-Abraín, A., and Oro, D. (2013). Preventing the development of dogmatic approaches in conservation biology: a review. Biol. Conserv. 159, 539-547. doi: 10.1016/j.biocon.2012.10.020

Montevecchi, W. A., and Myers, R. A. (1997). Centurial and decadal oceanographic influences on changes in northern gannet populations and diets in the northwest Atlantic: implications for climate change. Ices J. Mar. Sci. 54, 608-614. doi: 10.1006/jmsc. 1997.0265

Morrison, K. W., Hipfner, J. M., Blackburn, G. S., and Green, D. J. (2011). Effects of extreme climate events on adult survival of three Pacific Auks. Auk 128, 707-715. doi: 10.1525/auk.2011.10198

Myres, M. T. (1979). "Long-term climatic and oceanographic cycles regulating seabird distributions and numbers," in U S Fish and Wildlife Service Wildlife Research Report. (San Francisco, CA).

Nevoux, M., and Barbraud, C. (2006). Relationships between sea ice concentration, sea surface temperature and demographic traits of thin-billed prions. Polar Biol. 29, 445-453. doi: 10.1007/s00300-005-0075-4

Nevoux, M., Forcada, J., Barbraud, C., Croxall, J., and Weimerskirchi, H. (2010a). Bet-hedging response to environmental variability, an intraspecific comparison. Ecology 91, 2416-2427. doi: 10.1890/09-0143.1

Nevoux, M., Weimerskirch, H., and Barbraud, C. (2007). Environmental variation and experience-related differences in the demography of the longlived black-browed albatross. J. Anim. Ecol. 76, 159-167. doi: 10.1111/j.13652656.2006.01191.x

Nevoux, M., Weimerskirch, H., and Barbraud, C. (2010b). Long- and short-term influence of environment on recruitment in a species with highly delayed maturity. Oecologia 162, 383-392. doi: 10.1007/s00442-009-1482-y

Nogales, M., Martín, A., Tershy, B. R., Donlan, C. J., Veitch, D., Puerta, N., et al. (2004). A Review of Feral Cat Eradication on Islands. Conserv. Biol. 18, 310-319. doi: 10.1111/j.1523-1739.2004.00442.x

Olsson, O., and van der Jeugd, H. P. (2002). Survival in king penguins Aptenodytes patagonicus: temporal and sex-specific effects of environmental variability. Oecologia 132, 509-516. doi: 10.1007/s00442-002-0985-6

Oro, D., and Furness, R. W. (2002). Influences of food availability and predation on survival of kittiwakes. Ecology 83, 2516-2528. doi: 10.1890/00129658(2002)083[2516:IOFAAP]2.0.CO;2

Oro, D., Genovart, M., Ruiz, X., Jiménez, J., and García-Gans, J. (1996). Differences in diet, population increase and breeding performance between two colonies of Audouin's Gulls Larus audouinii during breeding seasons affected by a trawling moratorium. J. Avian Biol. 27, 245-251. doi: 10.2307/3677229

Oro, D., Pradel, R., and Lebreton, J.-D. (1999). Food availability and nest predation influence life history traits in Audouin's gull, Larus audouinii. Oecologia 118, 438-445. doi: 10.1007/s004420050746

Oro, D., Torres, R., Rodriguez, C., and Drummond, H. (2010). Climatic influence on demographic parameters of a tropical seabird varies with age and sex. Ecology 91, 1205-1214. doi: 10.1890/09-0939.1

Pardo, D., Barbraud, C., Authier, M., and Weimerskirch, H. (2013). Evidence for an age-dependent influence of environmental variations on a long-lived seabird's life-history traits. Ecology 94, 208-220. doi: 10.1890/12-0215.1

Parmesan, C. (2006). Ecological and evolutionary responses to recent climate change. Annu. Rev. Ecol. Evol. Syst. 37, 637-669. doi: 10.1146/annurev.ecolsys. 37.091305.110100

Peacock, L., Paulin, M., and Darby, J. (2000). Investigations into climate influence on population dynamics of yellow-eyed penguins Megadyptes antipodes. N.Z. J. Zool. 27, 317-325. doi: 10.1080/03014223.2000.9518241

Quillfeldt, P., and Masello, J. F. (2013). Impacts of climate variation and potential effects of climate change on South American seabirds - a review. Mar. Biol. Res. 9, 337-357. doi: 10.1080/17451000.2012.756982

Ramos, R., Granadeiro, J. P., Nevoux, M., Mougin, J.-L., Dias, M. P., and Catry, P. (2012). Combined spatio-temporal impacts of climate and longline fisheries on the survival of a trans-equatorial marine migrant. PLoS ONE 7:e40822. doi: 10.1371/journal.pone.0040822 
Regehr, H. M., and Montevecchi, W. A. (1997). Interactive effects of food shortage and predation on breeding failure of black-legged kittiwakes: indirect effects of fisheries activities and implications for indicator species. Mar. Ecol. Prog. Ser. 155, 249-260. doi: 10.3354/meps155249

Regular, P. M., Shuhood, F., Power, T., Montevecchi, W. A., Robertson, G. J., Ballam, D., et al. (2009). Murres, capelin and ocean climate: inter-annual associations across a decadal shift. Environ. Monit. Assess. 156, 293-302. doi: 10.1007/s10661008-0484-2

Reiertsen, T. K., Erikstad, K. E., Barrett, R. T., Sandvik, H., and Yoccoz, N. G. (2012). Climate fluctuations and differential survival of bridled and nonbridled Common Guillemots Uria aalge. Ecosphere 3, art52. doi: 10.1890/ES12$00031 \mathrm{R}$

Rivalan, P., Barbraud, C., Inchausti, P., and Weimerskirch, H. (2010). Combined impacts of longline fisheries and climate on the persistence of the Amsterdam Albatross Diomedia amsterdamensis. Ibis 152, 6-18. doi: 10.1111/j.1474919X.2009.00977.x

Robert, A., Paiva, V. H., Bolton, M., Jiguet, F., and Bried, J. (2012). The interaction between reproductive cost and individual quality is mediated by oceanic conditions in a long-lived bird. Ecology 93, 1944-1952. doi: 10.1890/11-1840.1

Rogelj, J., McCollum, D. L., Reisinger, A., Meinshausen, M., and Riahi, K. (2013). Probabilistic cost estimates for climate change mitigation. Nature 493, 79-83. doi: 10.1038/nature11787

Rolland, V., Barbraud, C., and Weimerskirch, H. (2008). Combined effects of fisheries and climate on a migratory long-lived marine predator. J. Appl. Ecol. 45, 4-13. doi: 10.1111/j.1365-2664.2007.01360.x

Rolland, V., Barbraud, C., and Weimerskirch, H. (2009a). Assessing the impact of fisheries, climate and disease on the dynamics of the Indian yellow-nosed Albatross. Biol. Conserv. 142, 1084-1095. doi: 10.1016/j.biocon.2008.12.030

Rolland, V., Nevoux, M., Barbraud, C., and Weimerskirch, H. (2009b). Respective impact of climate and fisheries on the growth of an albatross population. Ecol. Appl. 19, 1336-1346. doi: 10.1890/08-1060.1

Rolland, V., Weimerskirch, H., and Barbraud, C. (2010). Relative influence of fisheries and climate on the demography of four albatross species. Glob. Change Biol. 16, 1910-1922. doi: 10.1111/j.1365-2486.2009.02070.x

Ruffino, L., Bourgeois, K., Vidal, E., Duhem, C., Paracuellos, M., Escribano, F., et al. (2009). Invasive rats and seabirds after 2,000 years of an unwanted coexistence on Mediterranean islands. Biol. Invasions 11, 1631-1651. doi: 10.1007/s10530008-9394-z

Sabarros, P. S., Durant, J. M., Gremillet, D., Crawford, R. J. M., and Stenseth, N. C. (2012). Differential responses of three sympatric seabirds to spatiotemporal variability in shared resources. Mar. Ecol. Prog. Ser. 468, 291-301. doi: 10.3354/meps09972

Sandvik, H., Erikstad, K. E., Barrett, R. T., and Yoccoz, N. G. (2005). The effect of climate on adult survival in five species of North Atlantic seabirds. J. Anim. Ecol. 74, 817-831. doi: 10.1111/j.1365-2656.2005.00981.x

Sandvik, H., Reiertsen, T. K., Erikstad, K. E., AnkerNilssen, T., Barrett, R. T., Lorentsen, S., et al. (2014). The decline of Norwegian kittiwake populations: modelling the role of ocean warming. Clim. Res. 60, 91-102. doi: $10.3354 / \mathrm{cr} 01227$

Schreiber, E. A. (2002). "Climate and weather effects on seabirds," in Biology of Marine Birds, eds E. A. Schreiber and J. Burger (Boca Raton, FL: CRC Press), 179-216.

Schreiber, E. A., and Burger, J. (2002). Biology of Marine Birds. New York, NY: CRC Press.

Scott, B. E., Sharples, J., Wanless, S., Ross, O. N., Frederiksen, M., and Daunt, F. (2006). The use of biologically meaningful oceanographic indices to separate the effects of climate and fisheries on seabird breeding success. Conserv. Biol. 12, 46-62. doi: 10.1017/СBO9780511541964.005

Servanty, S., Gaillard, J.-M., Ronchi, F., Focardi, S., Baubet, É., and Gimenez, O. (2011). Influence of harvesting pressure on demographic tactics: implications for wildlife management. J. Appl. Ecol. 48, 835-843. doi: 10.1111/j.13652664.2011.02017.x

Sherley, R. B., Ludynia, K., Underhill, L. G., Jones, R., and Kemper, J. (2012). Storms and heat limit the nest success of Bank Cormorants: implications of future climate change for a surface-nesting seabird in southern Africa. J. Ornithol. 153 , 441-455. doi: 10.1007/s10336-011-0760-8

Smith, P. A., and Gaston, A. J. (2012). Environmental variation and the demography and diet of thick-billed murres. Mar. Ecol. Prog. Ser. 454, 237-249. doi 10.3354/meps09589
Soldatini, C., Albores-Barajas, Y. V., Massa, B., and Gimenez, O. (2014). Climate driven life histories: the case of the mediterranean storm petrel. PLOS ONE 9:e94526. doi: 10.1371/journal.pone.0094526

Stearns, S. C., Kaiser, M., and Kawecki, T. J. (1995). The differential genetic and environmental canalization of fitness components in Drosophila melanogaster. J. Evol. Biol. 8, 539-557. doi: 10.1046/j.1420-9101.1995.8050539.x

Sutherland, W. J. (2006). Predicting the ecological consequences of environmental change: a review of the methods. J. Appl. Ecol. 43, 599-616. doi: 10.1111/j.13652664.2006.01182.x

Sydeman, W. J., Hester, M. M., Thayer, J. A., Gress, F., Martin, P., and Buffa, J. (2001). Climate change, reproductive performance and diet composition of marine birds in the southern California Current system, 1969-1997. Prog. Oceanogr. 49, 309-329. doi: 10.1016/S0079-6611(01)00028-3

Sydeman, W. J., Mills, K. L., Santora, J. A., Thompson, S. A., Bertram, D. F., Morgan, K. H., et al. (2009). Seabirds and climate in the California current-a synthesis of change. Calif. Coop. Ocean. Fish. Investig. Rep. 50, 82-104.

Sydeman, W. J., Thompson, S. A., and Kitaysky, A. (2012). Seabirds and climate change: roadmap for the future. Mar. Ecol. Prog. Ser. 454, 107-117. doi: 10.3354/meps09806

Tavecchia, G., Minguez, E., De LeÇün, A., Louzao, M., and Oro, D. (2008). Living close, doing differently: Small-scale asynchrony in demography of two species of seabirds. Ecology 89, 77-85. doi: 10.1890/06-0326.1

Tavecchia, G., Pradel, R., Genovart, M., and Oro, D. (2007). Density-dependent parameters and demographic equilibrium in open population. Oikos 116, 1481-1492. doi: 10.1111/j.0030-1299.2007.15791.x

Thompson, P. M., and Ollason, J. C. (2001). Lagged effects of ocean climate change on fulmar population dynamics. Nature 413, 417-420. doi: 10.1038/35096558

Velarde, E., Ezcurra, E., Cisneros-Mata, M. A., and Lavín, M. F. (2004). Seabird ecology, El Niño anomalies, and prediction of sardine fisheries in the gulf of California. Ecol. Appl. 14, 607-615. doi: 10.1890/02-5320

Viera, V. M., Le Bohec, C., Cote, S. D., and Groscolas, R. (2006). Massive breeding failures following a tsunami in a colonial seabird. Polar Biol. 29, 713-716. doi: 10.1007/s00300-006-0128-3

Votier, S. C., Bearhop, S., Attrill, M. J., and Oro, D. (2008a). Is climate change the most likely driver of range expansion for a critically endangered top predator in northeast Atlantic waters? Biol. Lett. 4, 204-205. doi: 10.1098/rsbl.2007.0558

Votier, S. C., Birkhead, T. R., Oro, D., Trinder, M., Grantham, M. J., Clark, J. A., et al. (2008b). Recruitment and survival of immature seabirds in relation to oil spills and climate variability. J. Anim. Ecol. 77, 974-983. doi: 10.1111/j.13652656.2008.01421.x

Wakefield, E., Phillips, R., and Matthiopoulos, J. (2009). Quantifying habitat use and preferences of pelagic seabirds using individual movement data: a review. Mar. Ecol. Prog. Ser. 391, 165-182. doi: 10.3354/meps08203

Weimerskirch, H. (2002). "Seabird demography and its relationship with the marine environment," in Biology of Marine Birds, eds E. A. Schreiber and J. Burger (New York, NY: CRC press), 115-135.

Weimerskirch, H., Louzao, M., de Grissac, S., and Delord, K. (2012). Changes in wind pattern alter Albatross distribution and life-history traits. Science 335, 211-214. doi: 10.1126/science. 1210270

Woehler, E., Patterson, T. A., Bravington, M. V., Hobday, A. J., and Chambers, L. E. (2014). Climate and competition in abundance trends in native and invasive Tasmanian gulls. Mar. Ecol. Prog. Ser. 511, 249-263. doi: 10.3354/meps 10886

Conflict of Interest Statement: The author declares that the research was conducted in the absence of any commercial or financial relationships that could be construed as a potential conflict of interest.

Received: 27 October 2014; accepted: 21 November 2014; published online: 08 December 2014

Citation: Oro D (2014) Seabirds and climate: knowledge, pitfalls, and opportunities. Front. Ecol. Evol. 2:79. doi: 10.3389/fevo.2014.00079

This article was submitted to Interdisciplinary Climate Studies, a section of the journal Frontiers in Ecology and Evolution.

Copyright $\odot 2014$ Oro. This is an open-access article distributed under the terms of the Creative Commons Attribution License (CC BY). The use, distribution or reproduction in other forums is permitted, provided the original author(s) or licensor are credited and that the original publication in this journal is cited, in accordance with accepted academic practice. No use, distribution or reproduction is permitted which does not comply with these terms. 